\title{
LAS PINTURAS RUPESTRES DE LAS CUEVAS DE PIZACOMA Julián Palacios
}

El Altiplano del Titicaca conserva una abundante variedad de restos de las culturas precolombinas, tales como las "llallahuas" o habitaciones primitivas hechas de puramente piedra como las que todavía se ven en Tancatenca y la isla de Taquilam, las "chacas" especie de altaros en las cumbres de algunos cerros donde ofrecen sus sacrificios y ofrendas a la tierra y al sol; los "cachis" o cuarteles, los "pucaras", las "chullpas", etc., que por la premura del tiempo no ha sido posible traer estudios a la consideración de la Mesa Redonda, pero sería imperdonable dejar de dar siquiera una somera noticia de las "pinturas rupestres" de las cuevas de Pizacoma, descubiertas por el arqueólogo Dr. José María Franco Inojosa que vive en Juli.

En un reportaje publicado en "El Sol" del Cuzco del 9 de enero de 1957, Franco dice así: "Cuando la ciencia a través de años de estudio, se hace raíz en uno, emoción, la teoría hay que aplicar a la realidad. Y es así que mi viaje de fines de 1944 al distrito de Pizacoma, en mi deambular de explorador de la Arqueología, di con las cuevas que parecían aguardar el ojo avisor del estudioso, gracias a las finas atenciones del Señor Marcelino Herrera, hace pues 12 años que descubrí parte de las famosas pinturas rupestres de las cuevas de Pizacoma.
Las cuevas descubiertas entonces son cuatro: "Cullaca", que quiere decir en aimara hermana; "Qalluchu" (lugar donde se procrea"; "Pallqa" (bifurcación en este caso, de aguas", "Cututu" (el macho del cuy).

"Las cuevas se encuentran a 160 5' $50^{\prime}$ " de Latitud Sur, 69 22' 20" de longitud Oeste del Meridiano de Greenwich y a $3900 \mathrm{msnm}$, a poca distancia de la capital del Distrito de Pizacoma, Provincia de Chuchito, Departamento de Puno. Las cuevas están ubicadas en el farallón de rocas en semicírculo a partir de la alta cumbre de Chillmi, terminando en el lugar llamado Cututu, con una extensión aproximada de $25 \mathrm{~km}$ en desarrollo, donde existen numerosísimas cuevas, pero las cuevas son pinturas rupestres están en las cuevas orientadas de Este a Oeste. Ahora las cuevas se encuentran dentro de las propiedades particulares de Llallahua, comunidad, hacienda Posocono, de la Sra. Pastora Cáceres de Garnica y del Dr. Ernesto Salazar y de los herederos de Coaquira; hacienda Rosario de la Sra. Aste de Ticona y Cututu de los hermanos Tesillo.

"las imágenes representadas en las pinturas rupestres son escenas de la caza de vicuña y venados pintados de rojo, verde y negro; las figuras están siempre de perfil, sin que al ar- 
tista rupestre le interese la imagen del hombre en detalle, en este caso el simplismo llega al extremo. En las escenas de caza aparecen las trampas formadas con estacas con reticulado en colores y en series paralelas. Como una modalidad del medio ambiente se ve el uso de la cuerda (lazo) con las que están enlazadas las huicunas del cuello unas a otras, de las patas posteriores. Como este motivo central de las escenas de caza -y esto es muy importante para la Paleontología- se destaca en gran tamaño, con relación a las piezas cobradas de un posible felino. Relacionado con este mitológico animal desaparecido, hace unos años, se encontró en las cercanías de las cuevas, una vértebra fósil de gran tamaño, tanto que, por el agujero vertebral pasa el puño cerrado de un hombre, vértebra que felizmente se encuentra en buenas manos".

"En las escenas de caza fuera de las empalizadas paralelas aparecen verdaderos dédalos o laberintos rectangulares en forma espiral, teñidas las partes interiores en negro, rojo y verde, que sólo los especialistas en el manejo de esta clase de pintura y con la ayuda de lupas pueden descifrar y reconstruir, más todas ellas están muy dañadas por la mano del hombre posterior".

"De acuerdo a las pinturas murales, el hombre vestía una túnica sin mangas que abrigaba hasta media pierna, hecha de pellejos de animales sacrificados, unidas las costuras con guiadores del mismo material".

Estos son las noticias dadas por el Dr. José María Franco de las pinturas rupestres de las cuevas de Pizacoma que invitan a los estudiosos de esta Mesa Redonda, para que verifiquen y sequen las enseñanzas del caso. 